\title{
Effect of Integrated Nutrient Management on System's Total Productivity, System's Total Uptake and System's Total Economics of Maize and Wheat in Maize-Wheat Cropping Sequence in Mid Hills of H.P, India
}

\author{
Karan Verma*, A.D. Bindra and Janardan Singh \\ Department of Agronomy, Forages and Grassland Management, COA, CSK Himachal \\ Pradesh Krishi Vishvavidyalaya, Palampur, Himachal Pradesh- 176062 India \\ *Corresponding author
}

\begin{tabular}{|l|}
\hline Ke y w o r d s \\
Maize, Wheat, \\
Total System's \\
Productivity, Total \\
System's Uptake \\
and Total System's \\
economics
\end{tabular}

\section{A B S T R A C T}

On farm experiment was conducted at Department of Agronomy, Forages and Grassland Management, COA, CSK Himachal Pradesh Krishi Vishvavidyalaya, Palampur from kharif, 2015 to rabi, 2016-17. Experiment laid out in randomized block design with three replications comprising seven treatments i.e. 50\% nitrogen through FYM $+50 \%$ nitrogen through inorganic fertilizer; $50 \%$ nitrogen through fortified vermicompost $+50 \%$ nitrogen through inorganic fertilizer; $50 \%$ nitrogen through vermicompost $+50 \%$ nitrogen through inorganic fertilizer; $25 \%$ nitrogen through FYM $+75 \%$ nitrogen through inorganic fertilizer; $25 \%$ nitrogen through fortified vermicompost $+75 \%$ nitrogen through inorganic fertilizer; $25 \%$ nitrogen through vermicompost $+75 \%$ nitrogen through inorganic fertilizer and recommended dose of NPK through inorganic fertilizer and three treatments i.e. 50\% (recommended dose of NPK through inorganic fertilizers; 75\% RDF and 100\% RDF. All the seven treatments given to maize crop will act as main plot treatments for wheat during rabi season. System's total productivity, system's total uptake and system's total economics in maize-wheat cropping system was found statistically higher with the treatments $25 \% \mathrm{~N}$ through fortified vermicompost $+75 \% \mathrm{~N}$ through fertilizer $\left(\mathrm{T}_{5}\right)$ however, this remained statistically at par with recommended dose of fertilizer $\left(\mathrm{T}_{7}\right)$ in case of by product yield, total uptake and total economics during both the years. Application of $100 \% \mathrm{RDF}\left(\mathrm{F}_{3}\right)$ gave significantly higher system's total grain and stover/straw yield, total uptake and total economics followed by $75 \%$ RDF during both the seasons. The interaction effects between treatments in maize and wheat management did not significantly affect total systems grain and stover/straw yield, total uptake and total gross returns, net returns, benefit cost ratio during both the years.

\section{Introduction}

Maize (Zea mays L.) has become very popular cereal crop in India because of the increasing market price and high production potential of hybrid varieties in both irrigated as well as rainfed conditions. Moreover, in irrigated areas farmers fetch the income equal to the cash crops in comparatively short time period of 120-130 days by cultivating hybrid 
maize varieties. The productivity of maize is largely dependent on its nutrient management. It is well known fact that maize is a heavy feeder of nutrients and because of its $C_{4}$, nature it is very efficient in converting solar energy into production of dry matter. Globally, maize is known as Miracle crop and "Queen of Cereals" due to high genetic yield potentials than any other cereals counterpart (Kannan et al., 2013). India is the secondmost important maize growing country in Asia and world's sixth largest producer and the fifth largest consumer. In India, maize is cultivated in an area of 8.69 million hectares having production of 21.81 million tonnes with a productivity of $2509 \mathrm{~kg} \mathrm{ha}^{-1}$ (Anonymous 2017). Maize is the major crop of the Himachal Pradesh. The production of maize, which was cultivated on an area 0.30 million hectares having production 0.67 million tonnes with productivity of $2270 \mathrm{~kg}$ $\mathrm{ha}^{-1}$ (Anonymous 2017).

Wheat (Triticum aestivum L.) is the most important food-grain of India and is the staple food of millions of Indians, particularly in the northern and north-western parts of the country. It is world's second important cereal crop after rice. India is second largest producer of wheat in the world after China with about 12 per cent share in total world wheat production. Wheat is an important post monsoon crop of the country as India is ranking second in wheat production with an area of 30.2 million hectare having production of 93.5 million tonnes along with productivity of $3093 \mathrm{~kg} \mathrm{ha}$ (Anonymous 2017). In Himachal Pradesh, also wheat among other cereals occupies the largest area of about 0.35 million hectare with total production of 0.68 million tonnes along with a productivity of $1968 \mathrm{~kg} \mathrm{ha}^{-1}$ (Anonymous 2017). Maize (Zea mays L.)-wheat (Triticum aestivum L.) both belonging to family Poaceae. It is the most dominant cropping system in the State of Himachal Pradesh, contributing about 85 per cent of the total food grain production in the state. However, the productivity of this existing cropping system in small and marginal farmer's field is very low (Chaudhary and Singh, 1992) besides having lower cropping intensity as the fields remain idle for nearly three months.

Nitrogen being a major plant food nutrient plays a vital role in plant growth system. It is an integral part of protein, enzyme and nucleic acids which are responsible for the development of chlorophyll and ultimately the nitrogen supply to plants is of utmost importance in all the crops. Jacob and Con (1963) reported that the excessive nitrogen stimulates protein synthesis to such a degree that most of carbohydrates are used in the formation of amino acids and proteins, while the formation of strengthening tissues is weakened. This results in spongy and weak tissues, predisposing plant to lodging, reducing their resistance to the attack of pests and diseases and to adverse weather conditions. Apart from this, a lower rate of protein synthesis subsequently causes a decrease in cell size especially cell division leading to stunted growth and poor development of physiological stages (Devlin 1979). Nitrogen fertilizer plays an important role in increasing the productivity of vegetable crops. However, increasing cost of chemical fertilizers often restricts their use, hence it becomes imperative to substitute nitrogen by some other cheap and easy available sources (organic manures and composts) which may partially meet the crop requirement.

The organic sources besides supplying $\mathrm{N}, \mathrm{P}$ and $\mathrm{K}$ also make unavailable source of elemental nitrogen, bound phosphorus, micronutrients, and decomposed plant residues into available form to facilitate plant to absorb the nutrients. But the combined use of chemical fertilizers along with various 
organic sources is capable of improving soil quality and crop productivity on long term basis. The enriched vermicompost is a mixture of vermicompost, natural minerals and microorganisms. It not only contains additional nutrients, but also takes less time for its production as compared to conventional vermicompost. Another benefit of the new compost is the ability to exchange ingredients and vary the concentrations of nutrients depending on the specific requirements of different plants and soils. Moreover, these effects are significantly exhibited in the cropping system where farmers are repeatedly adopting the same cropping system year after year. As cropping system serves as a component of integrated nutrient management (INM) for sustaining the productivity of the system through efficient nutrient cycling, balanced fertilization must be based on the concept of the cropping system to sustain productivity of a system as a whole rather than a single crop. Intensified and multiple cropping systems require judicious application of chemical, organic and bio-fertilizers for yield sustainability and improved soil health. Such integrated application is not only complementary but also has synergistic effects. Therefore, the nutrient needs of crop production systems can be met through integrated nutrient management and sustainable crop productivity, nutrient uptake and soil nutrient status in maize based cropping systems (Kemal and Abera, 2015).

The chemical fertilizers alone cannot meet the requirement of crops and cropping systems, because of their high cost and less residual effects of chemicals, hence there is increasing trend towards use of organic manures. Incorporation of organic matter either in the form of crop residues or farmyard manure/ vermicompost/compost are vital for supplementing plant nutrients and maintenance of soil fertility, as it is an important soil component which influences the physical, chemical and biological properties of soil. Incorporation of organic manures influence soil enzymatic activity either because of the composition of the added materials or they increase microbial activity of the soil (DeForest et al., 2012).

Farmyard manure application to the crop is an age old practice. Well decomposed FYM in addition to supplying of plant nutrients, acts as binding material and improves the soil physical properties. Beneficial effects of earth worms and their cast were known as early as in Darwin's era. But the potential of vermicompost to supply nutrients and to support beneficial microbes is being recognized recently. Vermicompost is rich in nitrogen fixers and other beneficial microbial population. Hence, these characters recognized the vermicompost as biofertilizer (Kale and Bano 1988). Judicious use of FYM with chemical fertilizers improves soil physical, chemical and biological properties and improves the crop productivity (Sharma et al., 2007). Since maize-wheat is one of the important cropping systems of the country as well as state of Himachal Pradesh.

\section{Materials and Methods}

A field experiment was conducted for two consecutive years from kharif (2015) to rabi (2016-17) at the experimental farm of Department of Agronomy, Forages and Grassland Management, COA, CSK Himachal Pradesh Krishi Vishvavidyalaya, Palampur. The experimental farm is situated at $32^{0} 6^{\prime} \mathrm{N}$ latitude and $76^{0} 3^{\prime} \mathrm{E}$ longitude and at an elevation of $1290 \mathrm{~m}$ above mean sea level in North Western Himalaya. The area represents the mid-hill zone of Himachal Pradesh. Agroclimatically, Palampur represents the sub-temperate humid zone of Himachal Pradesh which is characterized by mild summers (March to June) and cool 
winters. The mean weekly meteorological observations recorded at the meteorological observatory of the Department of Agronomy, Forages and Grassland Management, College of Agriculture, CSK HPKV, Palampur. Experiment laid out in randomized block design with three replications comprising seven treatments i.e. $50 \%$ nitrogen through $\mathrm{FYM}+50 \%$ nitrogen through inorganic fertilizer $\left(\mathrm{T}_{1}\right) ; 50 \%$ nitrogen through fortified vermicompost $+50 \%$ nitrogen through inorganic fertilizer $\left(\mathrm{T}_{2}\right) ; 50 \%$ nitrogen through vermicompost $+50 \%$ nitrogen through inorganic fertilizer $\left(\mathrm{T}_{3}\right) ; 25 \%$ nitrogen through FYM $+75 \%$ nitrogen through inorganic fertilizer $\left(\mathrm{T}_{4}\right) ; 25 \%$ nitrogen through fortified vermicompost + $75 \%$ nitrogen through inorganic fertilizer $\left(\mathrm{T}_{5}\right) ; 25 \%$ nitrogen through vermicompost + $75 \%$ nitrogen through inorganic fertilizer $\left(\mathrm{T}_{6}\right)$; and recommended dose of NPK through inorganic fertilizer $\left(\mathrm{T}_{7}\right)$ and three treatments i.e. $50 \%$ recommended dose of NPK through inorganic fertilizers $\left(\mathrm{F}_{1}\right) ; 75 \% \operatorname{RDF}\left(\mathrm{F}_{2}\right)$ and $100 \%$ RDF $\left(\mathrm{F}_{3}\right)$. All the seven treatments given to maize crop will act as main plot treatments for wheat during rabi season.

\section{Experimental details}

The field experiment consisted of 7 treatments in maize in kharif season which acted as main plots for wheat and 3 treatments in wheat during rabi season as sub plot factors with three replications; Cropping system studies; Combined system's productivity, nutrient uptake and economics were worked out by summing up these parameters for individual crops. However, BC ratio from the maize-wheat system was worked out as below:

Benefit cost ratio $=$

Net returns (Rs. ha $\left.{ }^{-1}\right)$

$\left[\left(\right.\right.$ cost of cultivation of wheat $\left(\mathrm{Rs} . \mathrm{ha}^{-1}\right)+$ cost of cultivation of maize (Rs. ha $\left.{ }^{-1}\right)$ ]

\section{Studies in the cropping sequence}

\section{Total productivity}

The total systems productivity was measured in term of total grain and stover/straw yield (maize+wheat) (Table 1) from the yearly sequence of maize-wheat. The total main (grain) and by product (stover/straw) yield in cropping sequence was significantly influenced due to fertility treatments during both the years. Owing to high individual main and by product yields of maize and wheat, application of $25 \% \mathrm{~N}$ through fortified vermicompost $+75 \% \mathrm{~N}$ through fertilizer $\left(\mathrm{T}_{5}\right)$ gave significantly higher system's main and by products yields during both the years.

However, this remained statistically at par with $50 \% \mathrm{~N}$ through fortified vermicompost + $50 \% \mathrm{~N}$ through fertilizer $\left(\mathrm{T}_{2}\right), 25 \% \mathrm{~N}$ through farm yard manure $+75 \% \mathrm{~N}$ through fertilizer $\left(\mathrm{T}_{4}\right)$ and $25 \% \mathrm{~N}$ through vermicompost $+75 \%$ $\mathrm{N}$ through fertilizer $\left(\mathrm{T}_{6}\right)$ and recommended dose of fertilizer $\left(\mathrm{T}_{7}\right)$ and even with $50 \% \mathrm{~N}$ through vermicompost $+50 \% \mathrm{~N}$ through fertilizer $\left(T_{3}\right)$ in case of by product yield during both the years. The results are in conformity with that of Verma et al., (2012); Bhat et al., (2013) and Babli (2014). Fertility treatments in wheat significantly influenced system's total main and by product yields during both the years owing to higher grain and stover/straw of maize and wheat. Application of $100 \%$ RDF $\left(\mathrm{F}_{3}\right)$ gave significantly higher system's total grain and stover/straw yield during both years followed by $75 \% \mathrm{RDF}$ during both the seasons. The interaction effects between treatments in maize and wheat management did not significantly affect total systems grain and stover/straw yield during both the years.

\section{Nitrogen uptake $\left(\mathrm{kg} \mathrm{ha}^{-1}\right)$}

Data on system's total nitrogen uptake have been presented in Table 2 and depicted in 
Figures 1a,b and 2a,b. Data showed that higher uptake of nitrogen was observed with application of $25 \% \mathrm{~N}$ through fortified vermicompost $+75 \% \mathrm{~N}$ through fertilizer $\left(\mathrm{T}_{5}\right)$, but found at par with recommended dose of fertilizer $\left(\mathrm{T}_{7}\right), 25 \% \quad \mathrm{~N}$ through vermicompost $+75 \% \mathrm{~N}$ through fertilizer $\left(\mathrm{T}_{6}\right), 25 \% \mathrm{~N}$ through farm yard manure $+75 \%$ $\mathrm{N}$ through fertilizer $\left(\mathrm{T}_{4}\right)$ and $50 \% \mathrm{~N}$ through fortified vermicompost $+50 \% \mathrm{~N}$ through fertilizer $\left(\mathrm{T}_{2}\right)$ during both the years. Similar results were also reported by Urkurkar et al., (2010); Prasad et al., (2010); Thakur et al., (2011) and Sharma et al., (2014). Fertility management in wheat also brought about significant variation in uptake of nitrogen system's during both the years. Application of $100 \%$ RDF $\left(\mathrm{F}_{3}\right)$ resulted in significantly higher $\mathrm{N}$ uptake followed by $75 \% \mathrm{RDF}$ during both years. The fertility treatment in maize and wheat did not significantly interact in influencing system's $\mathrm{N}$ uptake during both the years.

\section{Phosphorus uptake (kg ha $\left.{ }^{-1}\right)$}

The data on system's total phosphorus uptake have been given in Table 2 and Figures 3a,b and 4a,b. Data indicated that combined application of organic and inorganic sources of nutrients in maize significantly influenced total systems phosphorus uptake during both the years with similar trend as that of $\mathrm{N}$ uptake. Treatments, receiving higher amounts of fertilizer NPK resulted in higher uptake of P. Similar results were also reported by Gupta et al., (2014) and Sharma et al., (2014). Fertility treatments in wheat also brought about significant variation in systems total $\mathrm{P}$ uptake during both the years. Application of $100 \% \mathrm{RDF}\left(\mathrm{F}_{3}\right)$ remaining at par with $75 \%$ RDF resulted in significantly higher system's total P uptake over 50\% RDF during both the years. The fertility treatment in maize and wheat had non-significant interactions for total P uptake during both the years.

Table.1 Treatment effects on total system's main (grain) and by product (stover/straw) yield $\left(\mathrm{kg} \mathrm{ha}^{-1}\right)$

\begin{tabular}{|c|c|c|c|c|c|}
\hline \multirow{2}{*}{\multicolumn{2}{|c|}{$\begin{array}{l}\text { Treatment } \\
\text { In maize }\end{array}$}} & \multicolumn{2}{|c|}{ Grain yield $\quad\left(\mathrm{kgha}^{-1}\right)$} & \multicolumn{2}{|c|}{$\begin{array}{c}\text { Stover/Straw yield } \\
\left(\mathrm{kg} \mathrm{ha}^{-1}\right)\end{array}$} \\
\hline & & $2015-16$ & 2016-17 & $2015-16$ & $2016-17$ \\
\hline $\mathbf{T}_{1}$ & FYM $_{50 \mathrm{~N}}+$ Fertilizer $_{50 \mathrm{~N}}$ & 7251 & 7669 & 10551 & 11579 \\
\hline $\mathbf{T}_{2}$ & Forti. VC $_{50 \mathrm{~N}}+$ Fertilizer $_{50 \mathrm{~N}}$ & 7469 & 7834 & 10799 & 11880 \\
\hline $\mathbf{T}_{3}$ & VC $_{50 \mathrm{~N}}+$ Fertilizer $_{50 \mathrm{~N}}$ & 7303 & 7593 & 10657 & 11627 \\
\hline $\mathbf{T}_{4}$ & $\mathrm{FYM}_{25 \mathrm{~N}}+$ Fertilizer $_{75 \mathrm{~N}}$ & 7461 & 7847 & 10790 & 11722 \\
\hline $\mathbf{T}_{5}$ & Forti. VC $_{25 \mathrm{~N}}+$ Fertilizer $_{75 \mathrm{~N}}$ & 7819 & 7995 & 11194 & 12038 \\
\hline $\mathbf{T}_{6}$ & $\mathrm{VC}_{25 \mathrm{~N}}+$ Fertilizer $_{75 \mathrm{~N}}$ & 7616 & 7889 & 11041 & 11856 \\
\hline $\mathbf{T}_{7}$ & RDF & 7727 & 8059 & 11192 & 12113 \\
\hline \multicolumn{2}{|c|}{ SEm \pm} & 164 & 132 & 202 & 160 \\
\hline \multicolumn{2}{|c|}{$\mathrm{CD}(\mathrm{P}=\mathbf{0 . 0 5})$} & 505 & 407 & 622 & 493 \\
\hline \multicolumn{6}{|c|}{ In wheat } \\
\hline $\mathbf{F}_{1}$ & $50 \% \mathrm{RDF}$ & 7171 & 7376 & 10421 & 11228 \\
\hline $\mathbf{F}_{2}$ & $75 \% \mathrm{RDF}$ & 7475 & 7914 & 10815 & 11901 \\
\hline $\mathbf{F}_{3}$ & $100 \% \mathrm{RDF}$ & 7918 & 8232 & 11432 & 12363 \\
\hline \multicolumn{2}{|c|}{ SEm \pm} & 120 & 104 & 156 & 126 \\
\hline \multicolumn{2}{|c|}{$\mathrm{CD}(\mathrm{P}=0.05)$} & 348 & 301 & 452 & 365 \\
\hline
\end{tabular}

$\mathrm{FYM}=$ Farm yard manure, Forti=Fortified, $50 \mathrm{~N}=50 \%$ Nitrogen, $\mathrm{VC}=$ Vermicompost, RDF= Recommended dose of fertilizer 
Table.2 Effects of treatments on system's total NPK uptake $\left(\mathrm{kg} \mathrm{ha}^{-1}\right)$

\begin{tabular}{|c|c|c|c|c|c|c|c|}
\hline \multicolumn{2}{|c|}{ Treatment } & \multicolumn{6}{|c|}{ Total uptake $\left(\mathrm{kg} \mathrm{ha}^{-1}\right)$} \\
\hline & & \multicolumn{2}{|c|}{$\mathrm{N}$ uptake } & \multicolumn{2}{|c|}{ P uptake } & \multicolumn{2}{|c|}{ K uptake } \\
\hline \multicolumn{2}{|c|}{ In maize } & $2015-16$ & 2016-17 & $2015-16$ & $2016-17$ & $2015-16$ & $2016-17$ \\
\hline $\mathbf{T}_{1}$ & FYM $_{50 \mathrm{~N}}+$ Fertilizer $_{50 \mathrm{~N}}$ & 167.3 & 172.7 & 36.1 & 40.1 & 138.3 & 149.4 \\
\hline $\mathbf{T}_{2}$ & Forti. VC $_{50 \mathrm{~N}}+$ Fertilizer $_{50 \mathrm{~N}}$ & 173.1 & 179.7 & 39.4 & 42.7 & 148.7 & 156.8 \\
\hline $\mathbf{T}_{3}$ & VC $_{50 \mathrm{~N}}+$ Fertilizer $_{50 \mathrm{~N}}$ & 168.6 & 174.2 & 37.5 & 39.8 & 143.7 & 152.9 \\
\hline $\mathbf{T}_{4}$ & $\mathrm{FYM}_{25 \mathrm{~N}}+$ Fertilizer $_{75 \mathrm{~N}}$ & 176.3 & 178.2 & 38.8 & 40.2 & 146.4 & 153.2 \\
\hline $\mathbf{T}_{5}$ & Forti. $\mathrm{VC}_{25 \mathrm{~N}}+$ Fertilizer $_{75 \mathrm{~N}}$ & 185.0 & 184.6 & 41.1 & 42.5 & 156.7 & 161.5 \\
\hline$T_{6}$ & $\mathrm{VC}_{25 \mathrm{~N}}+$ Fertilizer $_{75 \mathrm{~N}}$ & 179.8 & 181.2 & 39.0 & 41.2 & 153.3 & 157.6 \\
\hline $\mathbf{T}_{7}$ & RDF & 181.5 & 187.7 & 41.6 & 44.0 & 158.9 & 163.8 \\
\hline \multicolumn{2}{|c|}{ SEm \pm} & 4.16 & 3.88 & 1.42 & 1.28 & 4.70 & 4.16 \\
\hline \multicolumn{2}{|c|}{$\mathrm{CD}(\mathrm{P}=\mathbf{0 . 0 5})$} & 12.8 & 12.0 & 4.4 & 3.9 & 14.5 & 12.8 \\
\hline \multicolumn{8}{|c|}{ In wheat } \\
\hline $\mathbf{F}_{1}$ & $50 \% \mathrm{RDF}$ & 166.7 & 168.7 & 37.0 & 38.4 & 143.5 & 147.1 \\
\hline $\mathbf{F}_{2}$ & $75 \%$ RDF & 174.6 & 180.9 & 39.2 & 41.6 & 149.4 & 158.3 \\
\hline $\mathbf{F}_{3}$ & $100 \% \mathrm{RDF}$ & 185.5 & 190.1 & 41.1 & 43.7 & 155.4 & 164.2 \\
\hline \multicolumn{2}{|c|}{ SEm \pm} & 2.72 & 3.22 & 0.87 & 1.10 & 3.08 & 2.88 \\
\hline \multicolumn{2}{|c|}{$\mathrm{CD}(\mathbf{P}=\mathbf{0 . 0 5})$} & 7.8 & 9.3 & 2.5 & 3.2 & 8.9 & 8.3 \\
\hline
\end{tabular}

FYM= Farm yard manure, Forti=Fortified, $50 \mathrm{~N}=50 \%$ Nitrogen, $\mathrm{VC}=$ Vermicompost, RDF= Recommended dose of fertilizer

Table.3 Effect of treatments on system's total gross, net returns and benefit cost ratio

\begin{tabular}{|c|c|c|c|c|c|c|c|}
\hline \multirow{2}{*}{\multicolumn{2}{|c|}{$\begin{array}{l}\text { Treatment } \\
\text { In maize }\end{array}$}} & \multicolumn{2}{|c|}{$\begin{array}{l}\text { Gross returns } \\
\quad\left(\text { Rs. ha }^{-1}\right)\end{array}$} & \multicolumn{2}{|c|}{$\begin{array}{l}\text { Net returns } \\
\left(\text { Rs. } \text { ha }^{-1}\right)\end{array}$} & \multicolumn{2}{|c|}{ Benefit cost ratio } \\
\hline & & \multirow{2}{*}{$\begin{array}{c}2015-16 \\
161948\end{array}$} & \multirow{2}{*}{\begin{tabular}{|c|}
$2016-17$ \\
174481
\end{tabular}} & \multirow{2}{*}{$\begin{array}{c}2015-16 \\
106682\end{array}$} & \multirow{2}{*}{$\begin{array}{r}2016-17 \\
119215\end{array}$} & \multirow{2}{*}{$\begin{array}{c}2015-16 \\
1.93\end{array}$} & \multirow{2}{*}{$\begin{array}{c}2016-17 \\
2.16\end{array}$} \\
\hline $\mathbf{T}_{1}$ & $\mathrm{FYM}_{50 \mathrm{~N}}+$ Fertilizer $_{50 \mathrm{~N}}$ & & & & & & \\
\hline $\mathbf{T}_{2}$ & Forti. $\mathrm{VC}_{50 \mathrm{~N}}+$ Fertilizer $_{50 \mathrm{~N}}$ & 164690 & 176788 & 108428 & 120526 & 1.93 & 2.14 \\
\hline $\mathbf{T}_{3}$ & $\mathrm{VC}_{50 \mathrm{~N}}+$ Fertilizer $_{50 \mathrm{~N}}$ & 161874 & 172633 & 105800 & 116559 & 1.89 & 2.08 \\
\hline $\mathbf{T}_{4}$ & $\mathrm{FYM}_{25 \mathrm{~N}}+$ Fertilizer $_{75 \mathrm{~N}}$ & 164478 & 176096 & 113784 & 125402 & 2.24 & 2.47 \\
\hline $\mathbf{T}_{5}$ & Forti. $\mathrm{VC}_{25 \mathrm{~N}}+$ Fertilizer $_{75 \mathrm{~N}}$ & 169657 & 177913 & 118735 & 126991 & 2.33 & 2.49 \\
\hline $\mathbf{T}_{6}$ & $\mathrm{VC}_{25 \mathrm{~N}}+$ Fertilizer $_{75 \mathrm{~N}}$ & 166468 & 175851 & 115582 & 124965 & 2.27 & 2.46 \\
\hline $\mathbf{T}_{7}$ & RDF & 167786 & 178435 & 118368 & 129017 & 2.40 & 2.61 \\
\hline \multicolumn{2}{|c|}{ SEm \pm} & 2380 & 1872 & 1944 & 1582 & 0.143 & 0.137 \\
\hline \multicolumn{2}{|c|}{$\mathrm{CD}(\mathrm{P}=\mathbf{0 . 0 5})$} & 7335 & 5770 & 5991 & 4876 & 0.44 & 0.40 \\
\hline \multicolumn{8}{|c|}{ In wheat } \\
\hline $\mathbf{F}_{1}$ & $50 \% \mathrm{RDF}$ & 155691 & 164216 & 103785 & 113450 & 2.00 & 2.23 \\
\hline $\mathbf{F}_{2}$ & $75 \% \mathrm{RDF}$ & 163921 & 177707 & 111132 & 124657 & 2.11 & 2.35 \\
\hline $\mathbf{F}_{3}$ & $100 \%$ RDF & 176214 & 186154 & 122542 & 131610 & 2.28 & 2.41 \\
\hline \multicolumn{2}{|c|}{ SEm \pm} & 1960 & 1524 & 1610 & 1360 & 0.08 & 0.054 \\
\hline \multicolumn{2}{|c|}{$\mathrm{CD}(\mathrm{P}=0.05)$} & 5676 & 4414 & 4663 & 3939 & 0.23 & 0.16 \\
\hline
\end{tabular}

FYM= Farm yard manure, Forti=Fortified, $50 \mathrm{~N}=50 \%$ Nitrogen, VC= Vermicompost, $\mathrm{RDF}=$ Recommended dose of fertilizer 
Fig.1 Effects of treatments in maize on system's total $\mathrm{N}$ uptake in grain and stover/straw during, (a) 2015-16 and (b) 2016-17
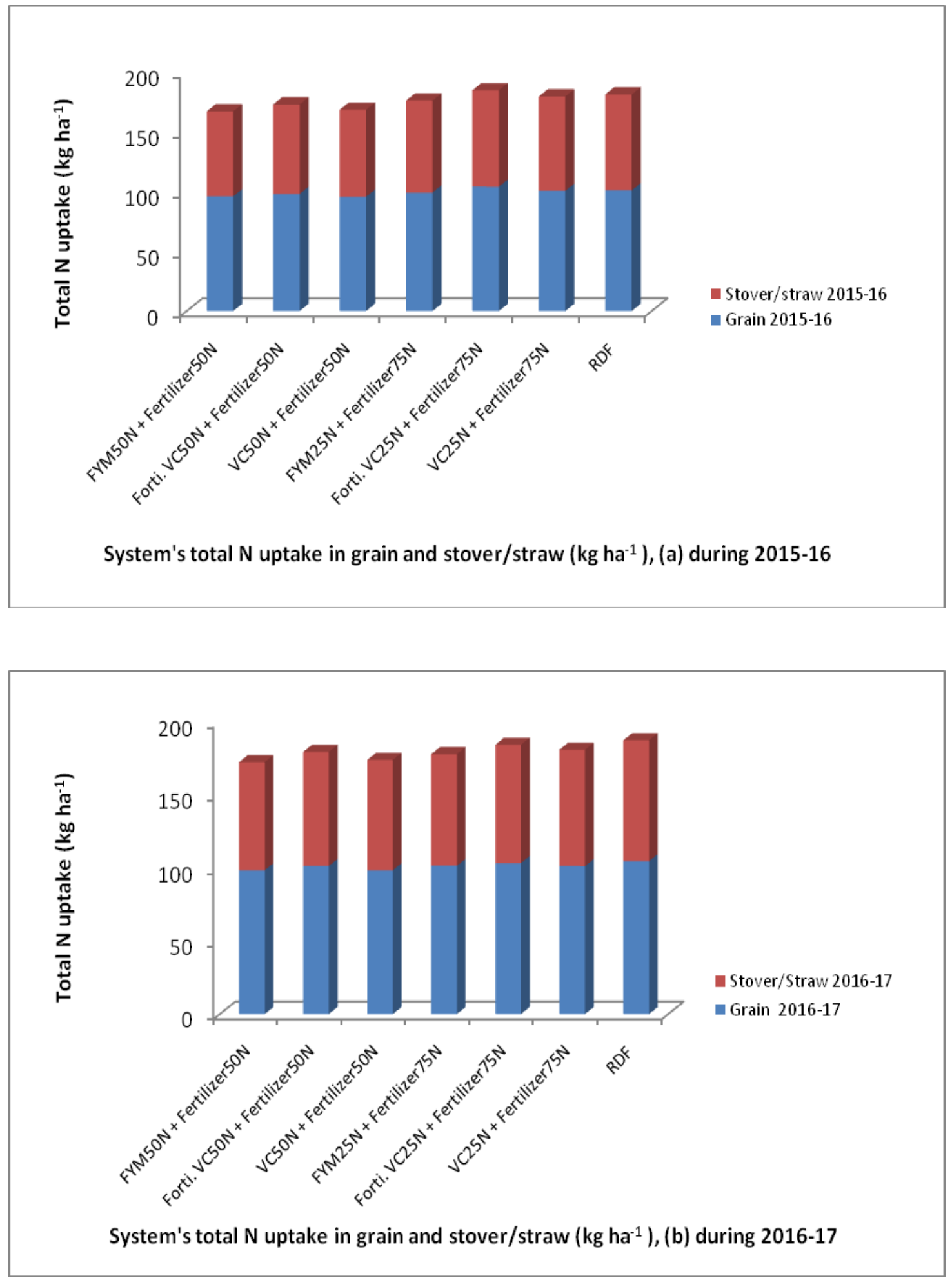
Fig.2 Fertility treatments in wheat on system's total $\mathrm{N}$ uptake grain and stover/straw during, (a) 2015-16 and (b) 2016-17
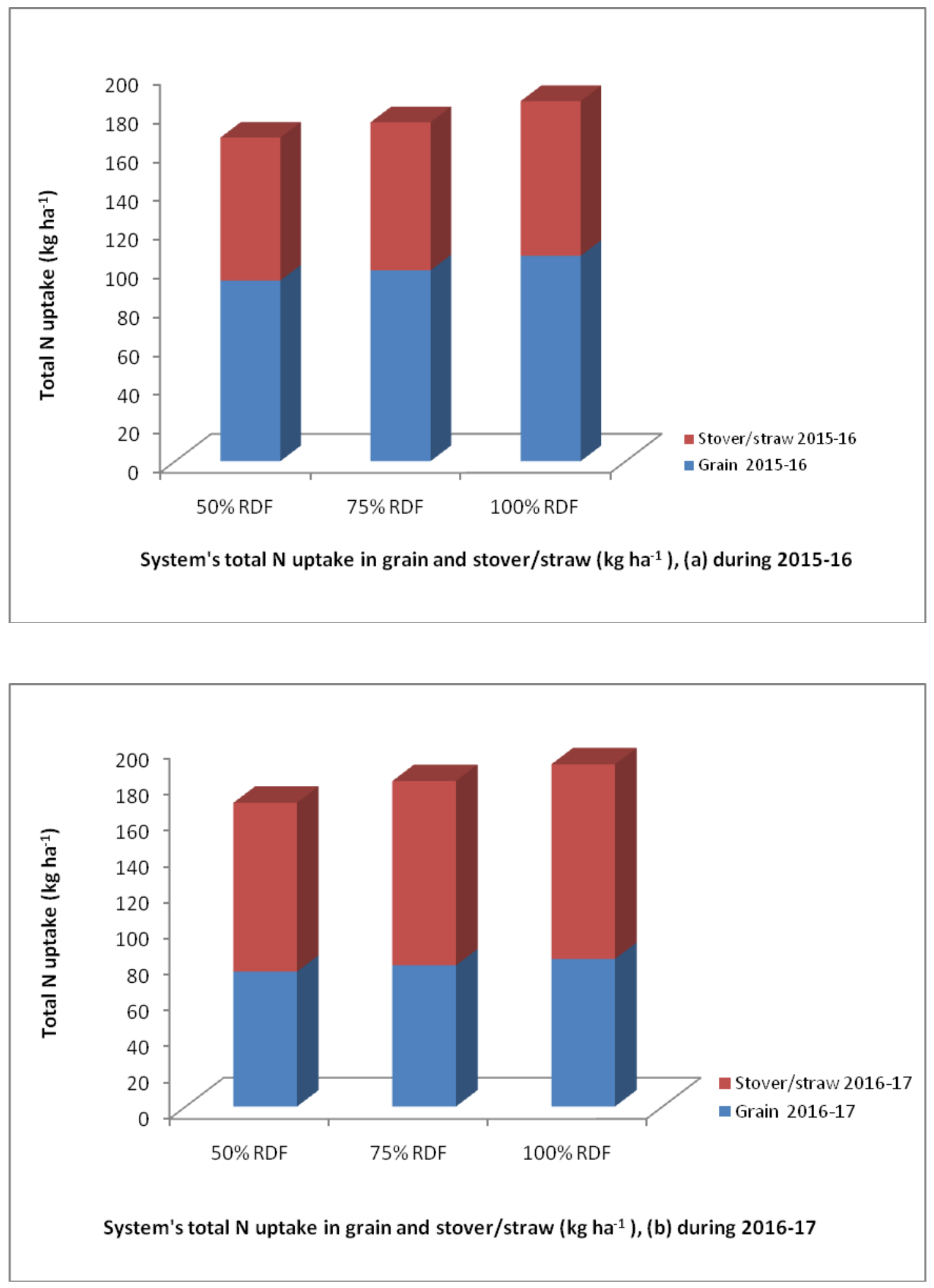
Fig.3 Effects of treatments in maize on system's total P uptake in grain and stover/straw during, (a) 2015-16 and (b) 2016-17
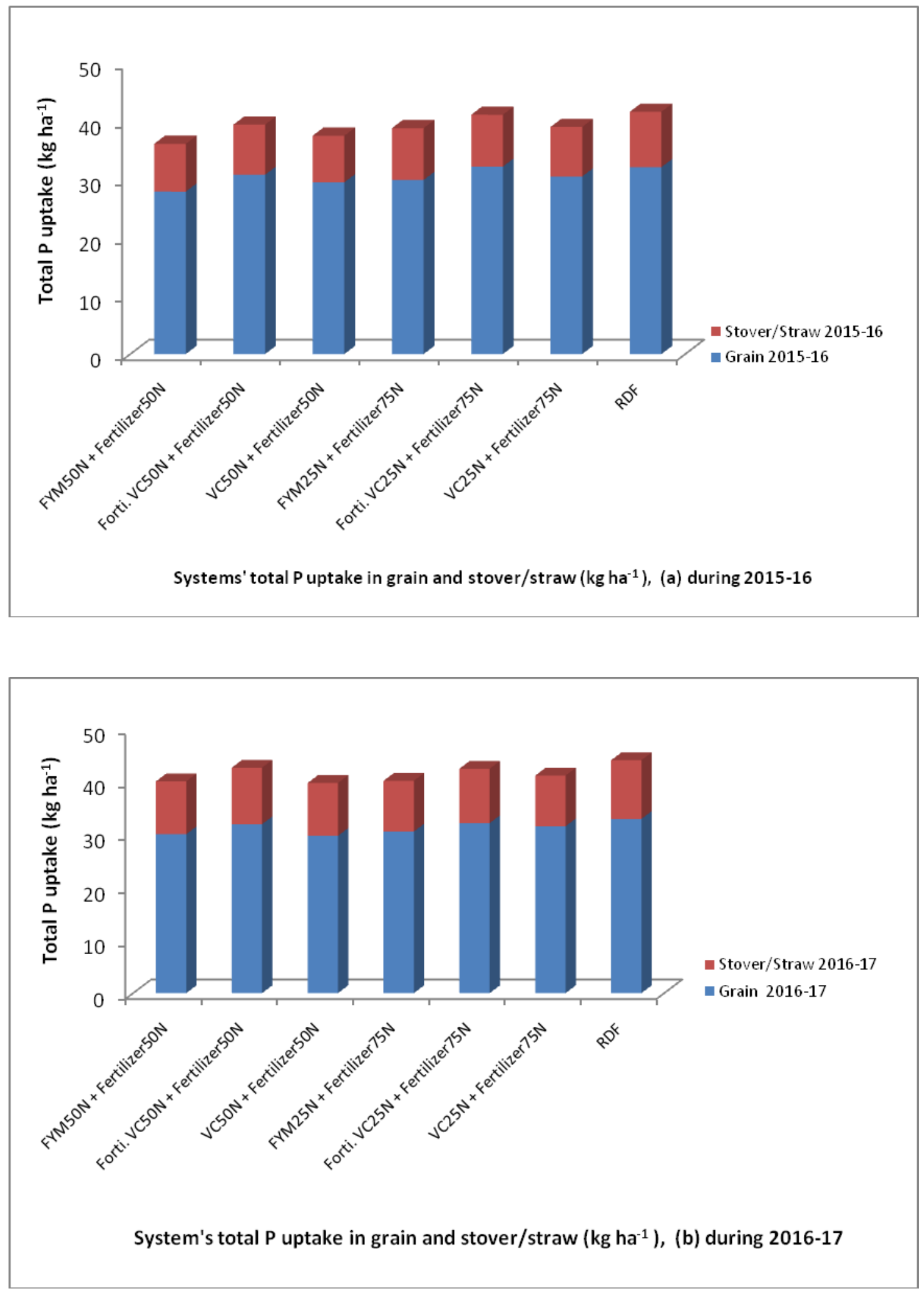
Fig.4 Fertility treatments in wheat on system's total P uptake grain and stover/straw during, (a) 2015-16 and (b) 2016-17
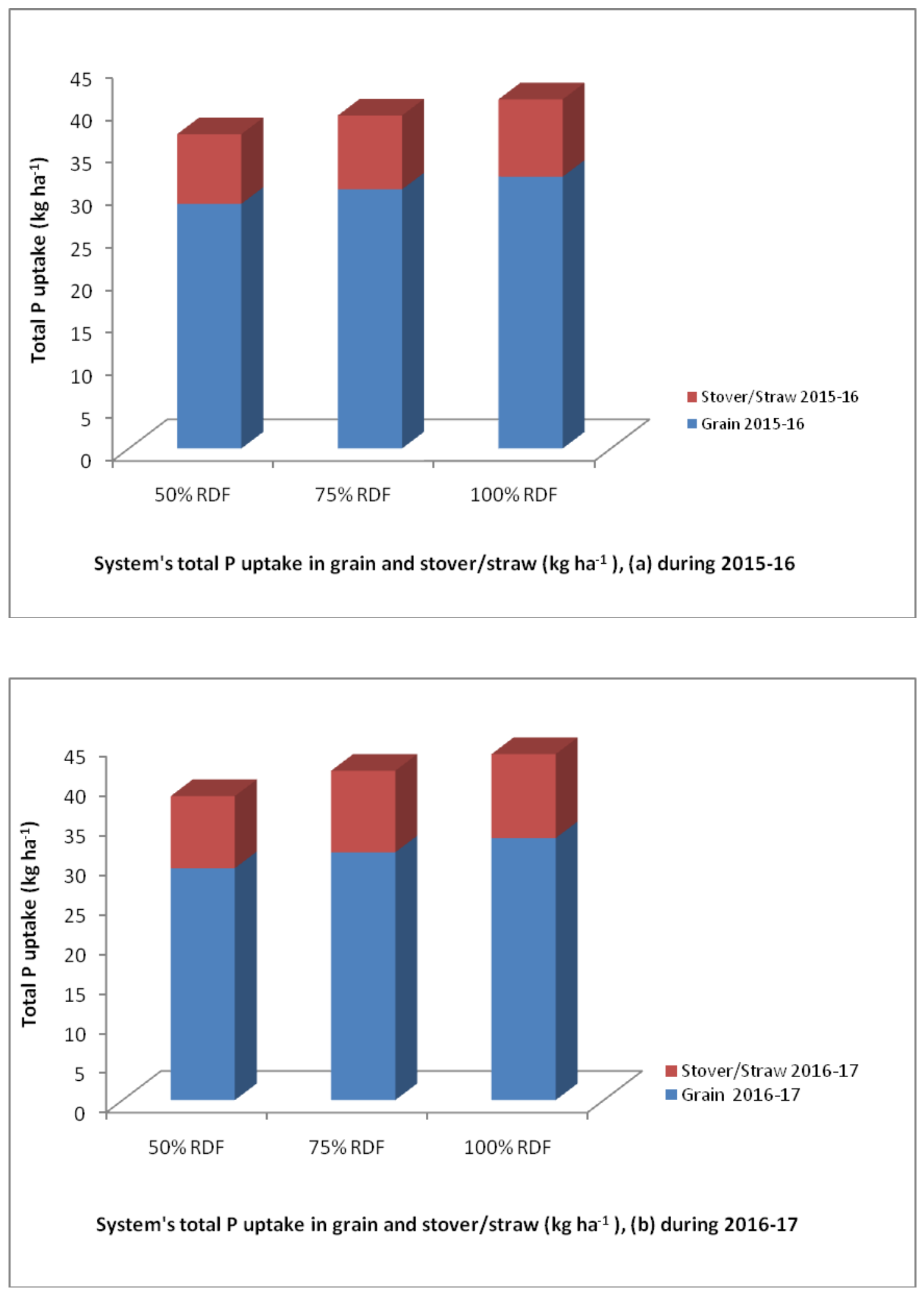
Fig.5 Effects of treatments in maize on system's total K uptake in grain and stover/straw during, (a) 2015-16 and (b) 2016-17
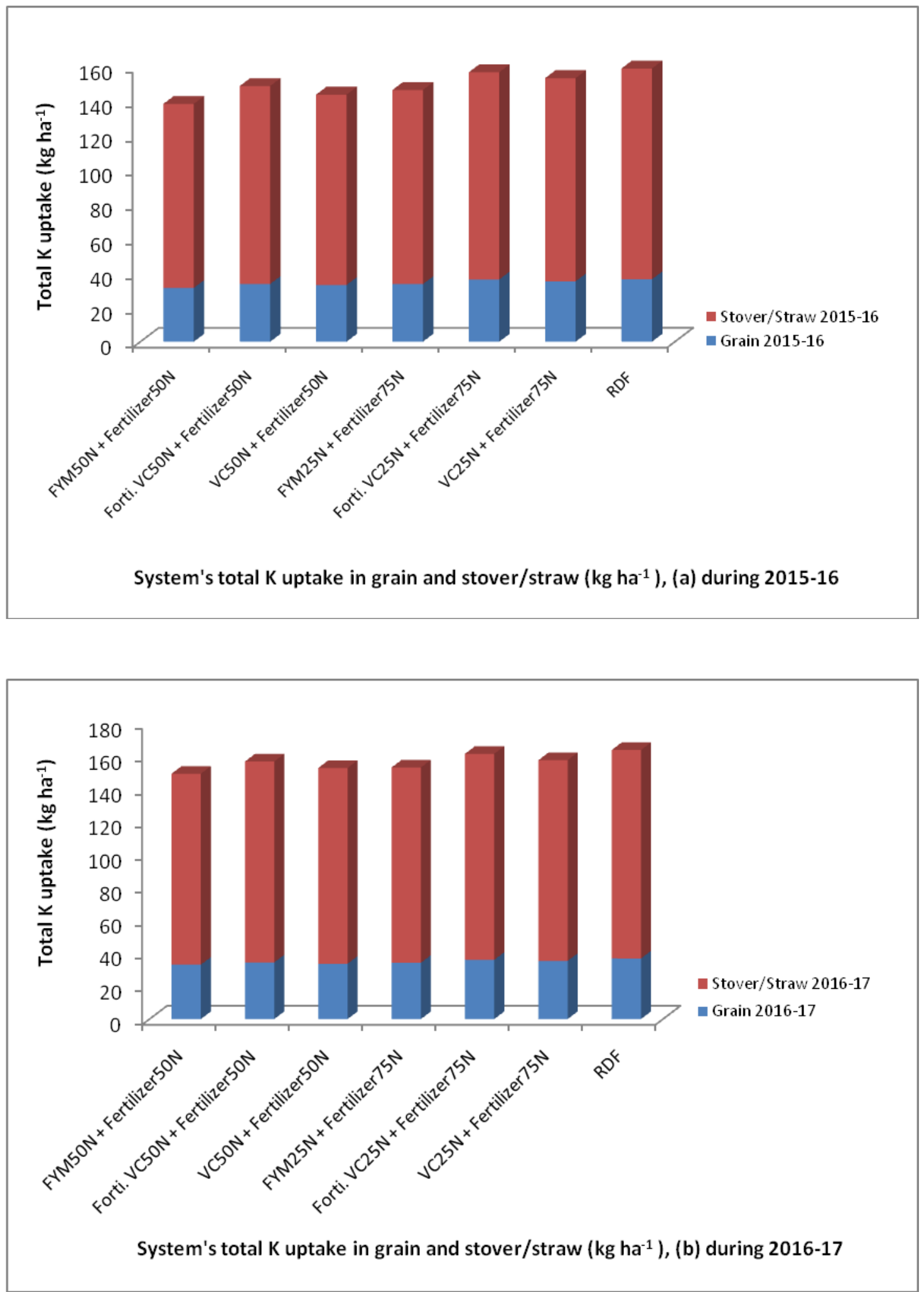
Fig.6 Fertility treatments in wheat on system's total K uptake grain and stover/straw during, (a) 2015-16 and (b) 2016-17
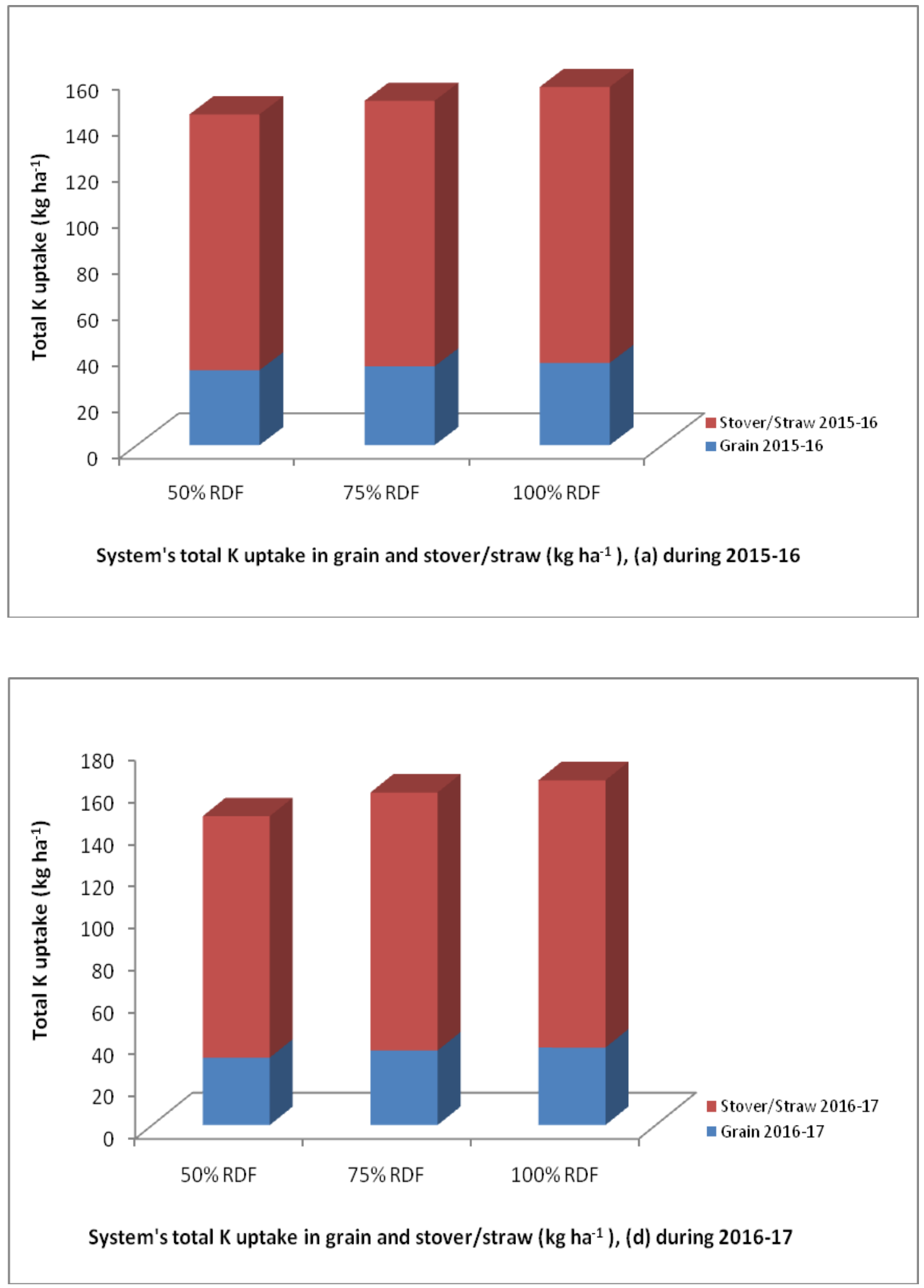


\section{Potassium uptake $\left(\mathrm{kg} \mathrm{ha}^{-1}\right)$}

The combined maize+wheat potassium uptake has been presented in Table 2 and Figures $5 a, b$ and 6a,b. Data showed that similar to $\mathrm{N}$ and $\mathrm{P}$ uptake, $\mathrm{K}$ uptake also followed same trend during both the years. It was further observed that direct application of NPK in more quantities resulted in higher $\mathrm{K}$ uptake. These finding are also in agreement with those of Prasad et al., (2010); Choudhary and Kumar (2013); Dwivedi et al., (2014); Sheoran et al., (2015) and Kakraliya et al., (2017). Fertility treatment in wheat also significantly influenced system total $\mathrm{K}$ uptake during both the years. Application of 100\% $\mathrm{RDF}\left(\mathrm{F}_{3}\right)$ remaining at par with $75 \% \mathrm{RDF}$ $\left(\mathrm{F}_{2}\right)$ gave significantly higher system's total $\mathrm{K}$ uptake over 50\% RDF $\left(\mathrm{F}_{2}\right)$ during both years. Interaction effects for total $\mathrm{K}$ uptake were not significant.

\section{Economic studies}

The maize-wheat system's total gross and net returns and benefit cost ratio have been given in Table 3. A perusal of the data revealed that application of $25 \% \mathrm{~N}$ through fortified vermicompost $+75 \% \mathrm{~N}$ through fertilizer $\left(\mathrm{T}_{5}\right)$ gave higher total gross returns, net returns and benefit cost ratio from maize-wheat cropping sequence during both the years. However, these treatments were statistically comparable to $25 \% \mathrm{~N}$ through farm yard manure $+75 \% \mathrm{~N}$ through fertilizer $\left(\mathrm{T}_{4}\right), 25 \% \mathrm{~N}$ through vermicompost $+75 \% \mathrm{~N}$ through fertilizer $\left(\mathrm{T}_{6}\right)$ and recommended dose of fertilizer $\left(\mathrm{T}_{7}\right)$ during both the years. The findings are in line with Ashok et al., (2008); Hashim et al., (2015) and Bandiwaddar et al., (2016). Different fertilizer levels applied to wheat also had significant variation in total gross and net returns and $\mathrm{BC}$ ratio. Application of $100 \% \operatorname{RDF}\left(\mathrm{F}_{3}\right)$ resulted in higher gross and net returns which was followed by $75 \%$ and $50 \%$ RDF during both the years. However, in case of benefit cost ratio application of $100 \%$ $\mathrm{RDF}$ and $75 \% \mathrm{RDF}$ were statistically at par with each other during both the years. Interaction between fertility treatments in maize and wheat was not significant for any of the economic parameters during both the years.

In conclusion, Substitution of $25 \%$ nitrogen through fortified vermicompost in maize crop was found comparable to chemical fertilizers in getting higher profitability of maize crop. For getting higher profitability in wheat, $100 \%$ NPK was better option. Hence, 25\% nitrogen could be saved in maize crop through fortified vermicompost to get higher productivity and profitability in maize-wheat cropping system.

\section{References}

Anonymous. 2017. Agricultural statistical a glance 2016. Directorate of economics and statistics, Department of Agricultural and Cooperation, Ministry of Agriculture and Farmers Welfare, Government of India pp 1-489

Ashok P, Pujari MBT, Hugar PS and Desai BK. 2008. Effect of micronutrients with or without organic manures on yield of baby corn (Zea mays L.)-chickpea (Cicer arietinum L.) sequence. Karnataka Journal of Agricultural Sciences 21 (4): 485-487

Babli. 2014. Effect of various nutrient sources on wheat in pearlmillet-wheat cropping system. M Sc. Thesis, Chaudhary Charan Singh Haryana Agricultural University, Hisar Haryana

Bandiwaddar TT, Patil BN, Patil NKB and Desai SA. 2016. Effect of zinc and iron enriched organics on growth, yield, keeping quality and economics of wheat (Triticum aestivum L.) in maize-wheat sequence cropping. Advances in Life Sciences 5 (6): 2186-2199 
Bhat RA, Ahmad L and Wani GA. 2013. Growth, yield and economics of maize as affected by cropping sequences, rates and frequency of farm yard manure. African Journal of Agricultural Research 8 (27): 3632-3638

Chaudhary JB and Singh CM. 1992. Study on production potential and economic evaluation of maize-based cropping system under mid hill conditions of Himachal Pradesh. Farming Systems 8 (3-4): 70-78

Choudhary and Kumar PS. 2013. Maize production, economics and soil productivity under different organic source of nutrients in eastern himalayan region, India. International Journal of Plant Production 7 (2): 167-186

DeForest JL, Smemo KA, Burke DJ, Elliot HL and Becker JC. 2012. Soil microbial responses to elevated phosphorus and $\mathrm{pH}$ in acidic temperate deciduous forests. Biogeochem 109: 189-202

Devlin RM. 1979. Plant Physiology. $3^{\text {rd }}$ Ed. Affiliated East West Press Pvt. Ltd. New Delhi

Dwivedi SK, Meshram MR and Pandey N. 2014. Response of customized fertilizer on wheat (Triticum aestivum) under Chhattisgarh conditions. The Bioscan 9 (4): 1509-1512

Gupta V, Sharma A, Kumar J, Abrol V, Singh V and Singh M. 2014. Effects of integrated nutrient management on growth and yield of maize (Zea mays)gobhi sarson (Brassica napus) cropping system in sub-tropical region under foothills of north-west Himalayas. Bangladesh Journal of Botany 43 (2): 147-155

Hashim M, Dhar S, Vyas AK, Pramesh V and Kumar V. 2015. Integrated nutrient management in maize (Zea mays)-wheat (Triticum aestivum) cropping system. Indian Journal of Agronomy 60 (3): 352-359
Jacob A and Con VH. 1963. Fertilizer Use (c.f. Arnon 1975)

Kakraliya SK, Jat RD, Kumar S, Choudhary KK, Prakash J and Singh LK. 2017. Integrated nutrient management for improving fertilizer use efficiency, soil biodiversity and productivity of wheat in irrigated rice wheat cropping system in Indo-Gangatic plains of India. International Journal of Current Microbiology and Applied Sciences 6 (3): 152-163

Kale RD and Bano K. 1988. Earthworm cultivation and culturing techniques for the production of vee COMP83E UAS.Mysore Journal Agricultural Science 2: 339-344

Kannan RL, Dhivya M, Abinaya D, Krishna RL and Kumar SK. 2013. Effect of integrated nutrient management on soil fertility and productivity in maize. Bulletin of Environment, Pharmacology and Life Sciences 2 (8): 61-67

Kemal YO and Abera M. 2015. Contribution of integrated nutrient management practices for sustainable crop productivity, nutrient uptake and soil nutrient status in maize based cropping systems. Journal of Nutrients 2 (1): 110

Prasad J, Karmakar S, Kumar R and Mishra B. 2010. Influence of integrated nutrient management on yield and soil properties in maize-wheat cropping system in an Alfisol of Jharkhand. Journal of the Indian Society of Soil Science 58 (2): 200-204

Sharma A, Singh H and Nanwal RK. 2007. Effect of nutrient management on productivity of wheat (Triticum aestivum) under limited and adequate irrigation supply. Indian Journal of Agronomy 52 (3): 120-123

Sharma RP, Kaushal V, Verma G and Sharma SP. 2014. Effect of three decade long application of chemical fertilizer 
and amendments on crop yield under maize-wheat cropping system in an acid alfisol. Journal of Applied and Natural Science 6 (1): 106-109

Sheoran HS, Duhan BS, Grewal KS and Sheoran S. 2015. Grain yield and NPK uptake of wheat (Triticum aestivum L.) as influenced by nitrogen, vermicompost and herbicide (Clodinafop propargyl). African Journal of Agricultural Research 10 (42): 39523961

Thakur R, Sawarkar SD, Vaishya UK and Singh M. 2011. Impact of continuous use of inorganic fertilizers and organic manure on soil properties and productivity under soybean-wheat intensive cropping of Vertisol. Journal of the Indian Society of Soil Science 59 (1): 74-81

Urkurkar JR, Tiwari A, Chitale S and Bajpai RK. 2010. Influence of long-term use of inorganic and organic manures on soil fertility and sustainable productivity of rice (Oryza sativa) and wheat (Triticum aestivum) in Inceptisols. Indian Journal of Agricultural Sciences 80 (3): 208-212

Verma G, Mathur AK and Verma A. 2012. Effect of continuous use of organics and inorganics on nutrient status of soil and yield under maize-wheat intensive cropping system in an Inceptisol. Journal of Soils and Crops 22 (2): 280286

\section{How to cite this article:}

Karan Verma, A.D. Bindra and Janardan Singh. 2018. Effect of Integrated Nutrient Management on System's Total Productivity, System's Total Uptake and System's Total Economics of Maize and Wheat in Maize-Wheat Cropping Sequence in Mid Hills of H.P, India Int.J.Curr.Microbiol.App.Sci. 7(12): 3488-3502. doi: https://doi.org/10.20546/ijcmas.2018.712.395 